\title{
TRACE ELEMENT SOLUBILITY AND REACTION KINETICS IN THE CAS-SYSTEM
}

\author{
Stephan Buhre ${ }^{1}$, Holger K. Steinberg ${ }^{1}$, Gerhard P. Brey ${ }^{1}$ and Simon M. Clark ${ }^{2}$ \\ ${ }^{1}$ University of Frankfurt, Germany; ${ }^{2}$ Lawrence Berkeley National Laboratory, USA
}

\section{INTRODUCTION}

A new locality of lower mantle inclusion bearing diamonds has been described recently from the Kankan district of Guinea (Stachel et al., 2000). Besides majoritic garnet and ferropericlase there are two new minerals: Ca-Si-titanite coexisting with larnite, and a $\mathrm{CaSiO}_{3}$ phase with walstromite structure (Joswig et al., 1999). From experiments (Gasparik et al., 1994) it is known that $\mathrm{Ca}$-Si-perovskite disproportionates to larnite and Si-titanite phase at pressures below $\sim 12 \mathrm{GPa}$ at $1200^{\circ} \mathrm{C}$. These two phases recombine to $\mathrm{Ca}$ walstromite at pressures below $\sim 10 \mathrm{GPa}$ (Fig. 1). One inclusion from Kankan consisted of larnite and Sititanite separated by a small zone of $\mathrm{CaSiO}_{3}$ (presumably with walstromite structure). More often $\mathrm{CaSiO}_{3}$ inclusions are found as an amorphous phase, possibly indicating a former Ca-perovskite. An understanding of the reaction kinetics in the $\mathrm{CaO}-\mathrm{SiO}_{2}$ system could help to reconstruct diamond ascent paths. A series of isothermal retrograde multianvil

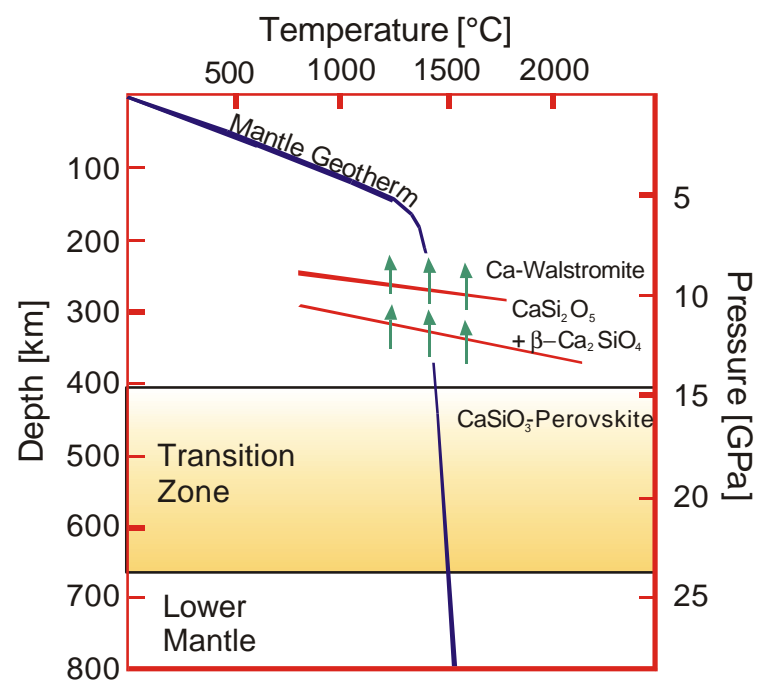

Figure 1: Temperature vs. Depth diagram showing the stability fields of Ca-silicate-phases. Green arrows represent experimental conditions of different isothermal runs. experiments were performed insitu at the Daresbury Synchrotron, which allow the determination of fundamental kinetic parameters. Such data are essential for reconstructing the ascent history of the host diamond.

To determine the depth from which these inclusions originated, we also investigated the maximum solubility of REE in Ca-silicates. We conducted a series of experiments with belt and multi-anvil apparatuses at pressures from 3.0 $\mathrm{GPa}$ to $15 \mathrm{GPa}$ and temperatures from $1200^{\circ} \mathrm{C}$ to $1500^{\circ} \mathrm{C}$. REE contents in the walstromite and perovskite structures coexisting with a Ca-REE-silicate phase $\mathrm{Ca}(\mathrm{Ca}, \mathrm{La}, \mathrm{Gd}, \mathrm{Lu}){ }_{2} \mathrm{Si}_{2} \mathrm{O}_{8}$ were determined. A further series of experiments was conducted to determine the maximum solubility of $\mathrm{K}$ and $\mathrm{P}$ in $\mathrm{Ca}$-walstromite coexisting with an apatite phase. These elements are of interest because of their high concentrations observed in the Ca-silicate inclusions from Kankan (Stachel et al, 2000).

\section{METHODS}

\section{REACTION KINETICS EXPERIMENTS}

The experiments were conducted in a Walker-type multi-anvil press which is installed on beamline 16.4. at the Daresbury synchrotron. This press is designed to allow insitu energy dispersive X-Ray diffraction (EDXRD). The three Germanium solid state detectors were calibrated using the method by Walker et al., 2000. A new pressure cell design was developed which allows insitu observation up to pressures of $15 \mathrm{GPa}$ and temperatures in exess of $1600^{\circ} \mathrm{C}$. Run pressures were calculated from the change of the lattice parameters of the $\mathrm{MgO}$ internal pressure standard (Fig 2). The temperature was controlled within $\pm 5^{\circ} \mathrm{C}$ using a S-type thermocouple (and D-type for high T).

The starting material for the kinetic study was $\mathrm{CaSiO}_{3}$ gel loaded into a $\mathrm{MgO} / \mathrm{Cr}_{2} \mathrm{O}_{3}$ - cell with a $\mathrm{LaCrO}_{3}$ heater in "fin to fin"-orientation (Fig. 2). The sample was first brought to pressure and then heated to $1200^{\circ} \mathrm{C}$. After the formation of Ca-perovskite the pressure was reduced at a constant rate into the larnite + Si-titanite stability field. The reaction rate was determined by collecting diffraction spectra every 180 seconds. Reaction at the sample-standard-interface was limited 
to $<50 \mu \mathrm{m}$ over a $24 \mathrm{~h}$ period and this area was avoided during meassurement. A Re sleeve prevented reaction with the surrounding $\mathrm{MgO}$ in the pressure cell.

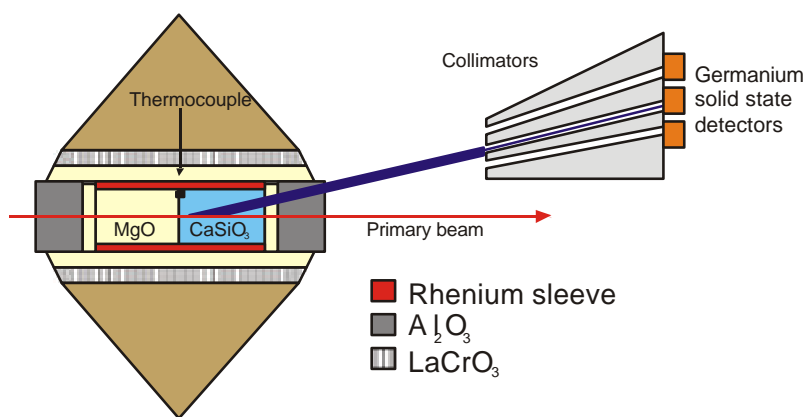

Figure 2: Experimental setup using white synchrotron radiation: data from $\mathrm{MgO}$ pressure standard and sample were collected by moving the whole multi-anvil press relative to the detector system.

\section{TRACE ELEMENT SOLUBILITY EXPERIMENTS}

Experiments up to $5 \mathrm{GPa}$ pressure were conducted in a belt apparatus using $\mathrm{CaF}_{2}$ single-crystal pressure media and graphite heaters. Experiments above $5 \mathrm{GPa}$ were performed in a Walker-type multi-anvil press using 14 $\mathrm{mm} \mathrm{MgO}$ octahedra, rhenium foil heaters and pyrophyllite gaskets. The starting material was prepared from element oxides and carbonates for the REE-series and from gels for the $\mathrm{K}$ and $\mathrm{P}$ runs (Table 1). For the REE runs $\mathrm{La}, \mathrm{Gd}$, Lu were added as a light, middle and heavy REE, respectively. These three elements were added as hydrated carbonates, which released a $\mathrm{CO}_{2} / \mathrm{H}_{2} \mathrm{O}$ fluid during the experiment. This fluid served as a flux to better achieve equilibrium. For the second series of experiments Mix2 (Table 1) was $\mathrm{CaSiO}_{3}$ gel with $\mathrm{K}$ and $\mathrm{P}$ added as potassiumdihydrogenphosphate. Starting material was fineground and sealed in $\mathrm{Pt}$ capsules without excess water. The experiment was loaded to the run pressure and subsequently heated at a rate of $50^{\circ} \mathrm{C} / \mathrm{min}$. Run durations were $72-96 \mathrm{~h}$. Experiments were quenched by switching off the electric power. The capsules were cut and polished for electron microprobe analysis.

\section{Table 1: composition of the starting materials (weight \% oxide)}

$\begin{array}{lll} & M i x 1(\mathrm{REE}) & \mathrm{Mix2}(\mathrm{K}, \mathrm{P}) \\ \mathrm{P}_{2} \mathrm{O}_{5} & ------ & 7.72 \\ \mathrm{SiO}_{2} & 43.34 & 44.57 \\ \mathrm{La}_{2}\left(\mathrm{CO}_{3}\right)_{2}{ }^{*} \times \mathrm{H}_{2} \mathrm{O} & 4.54 & ------ \\ \mathrm{Gd}_{2}\left(\mathrm{CO}_{3}\right)_{2}{ }^{*} \times \mathrm{H}_{2} \mathrm{O} & 4.90 & ------ \\ \mathrm{Lu}_{2}\left(\mathrm{CO}_{3}\right)_{2}{ }^{*} \times \mathrm{H}_{2} \mathrm{O} & 5.25 & ----- \\ \mathrm{Al}_{2} \mathrm{O}_{3} & 1.52 & ------ \\ \mathrm{CaO} & 40.45 & 41.60 \\ \mathrm{~K}_{2} \mathrm{O} & ------ & 5.12 \\ \mathrm{H} 2 \mathrm{O} & & 0.98 \\ \text { Total } & 100.00 & 99.99\end{array}$

\section{RESULTS AND DISCUSSION}

\section{KINETICS}

First results of retrograde high pressure experiments performed at $1200^{\circ} \mathrm{C}$ indicate that the disproportionation reaction of $\mathrm{Ca}$-perovskite to larnite + $\mathrm{Si}$-titanite proceeds at an order of magnitude faster than the recombinition to walstromite. This confirms what was deduced before from the natural diamond inclusions (Stachel et al. 2000):

Further phases were found as seperate inclusions in the same diamond which indicate that the touching paragenesis of larnite and $\mathrm{Si}$-titanite was originally $\mathrm{CaSiO}_{3}$ in perovskite structure. On uprise the dispropotionation reaction went to completion whereas the subsequent reaction to combine the two phases to $\mathrm{Ca}$-walstromite remained incomplete. This is consistent with our observation that this reaction is proceeding at a much slower rate than the disproportionation reaction. This "frozen" state of the Ca-walstromite formation is the key to reconstruct the ascent history of the host diamond.

The ongoing work at different temperatures will allow to deduce fundamental parameters (activation energy) and to model the ascent path of the mantle domain hosting the diamonds.

\section{REE-SOLUBILITY}

The solibility of the trace elements investigated was determined by EMS analysis. Since a REE-rich phase coexists with $\mathrm{CaSiO}_{3}$ and melt (Fig. 3), the REE-data represent the maximu $\mathrm{m}$ solubility in $\mathrm{Ca}$-walstromite. Table 2 shows some of the analytical data at upper mantle conditions. 


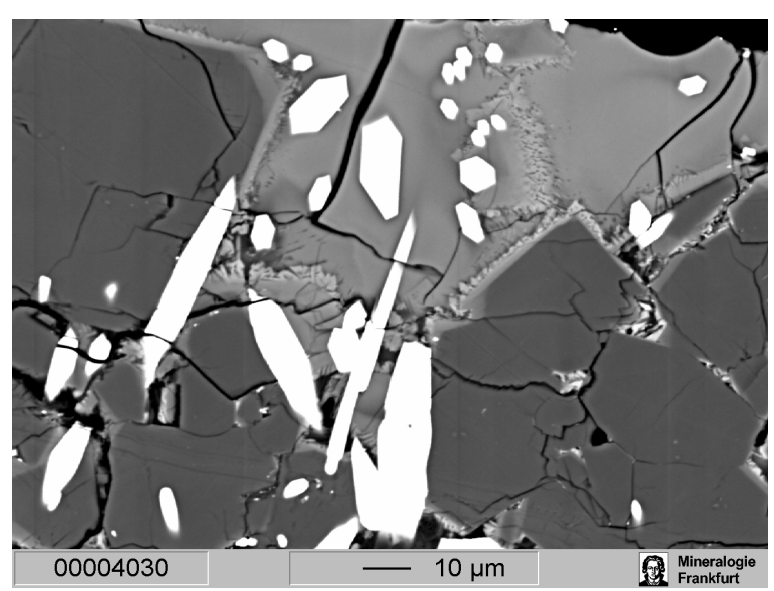

Figure 3 BSE image of run product KW323 (4.0 GPa, $1200^{\circ} \mathrm{C}$ ): Ca-walstromite (dark grey) coexisting with melt (light grey) and a REE phase (white hexagonal crystals)

\section{Table 2: maximum solubility ( $\mathrm{mol} \%$ of cations) of REE in Ca-walstromite}

$\begin{array}{lrr} & 4.0 \mathrm{Gpa} 1200^{\circ} \mathrm{C} & 6.0 \mathrm{GPa} 1300^{\circ} \mathrm{C} \\ \text { Si } & 50,21 & 50,48 \\ \text { Ca } & 49,45 & 49,15 \\ \text { Al } & 0,05 & 0,04 \\ \text { La } & 0,02 & 0,02 \\ \text { Gd } & 0,10 & 0,12 \\ \text { Lu } & 0,16 & 0,20\end{array}$

\section{K AND P SOLUBILITY}

The run products from this experimental series yielded Ca-walstromite coexisting with melt and an apatite phase, a buffer phase for the solubility of phosphorus. On a molar basis potassium in $\mathrm{Ca}$-wals tromite exeeds the value for $\mathrm{P}$ by a facor of $\sim 3$ (Fig. 5). Charge balance must then occur via vacancies which is in contrast to the findings from natural inclusions in diamond. There, $\mathrm{K}$ and $\mathrm{P}$ occur in a one to one ratio, which suggests solution as a $\mathrm{KPO}_{3}$-component (with $\mathrm{K}^{+}$replacing $\mathrm{Ca}^{2+}$ and $\mathrm{P}^{5+}$ replacing $\mathrm{Si}^{4+}$ ).

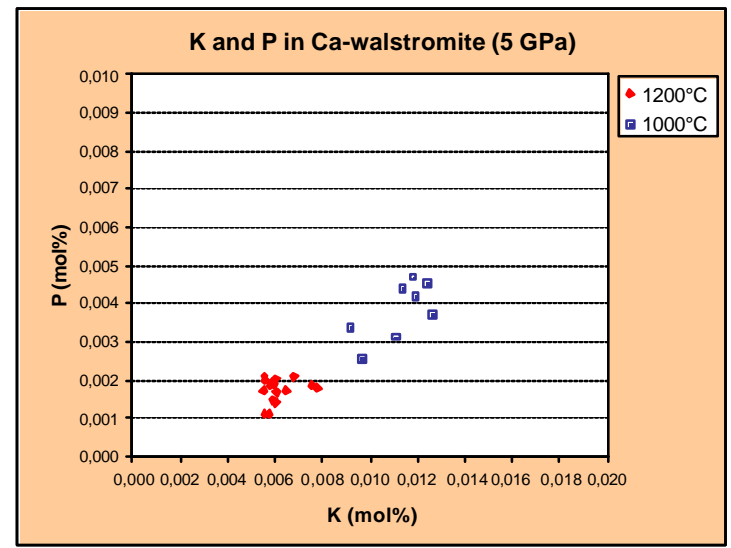

Figure 5: $\mathrm{K}$ and $\mathrm{P}$ solibility in Ca-walstromite

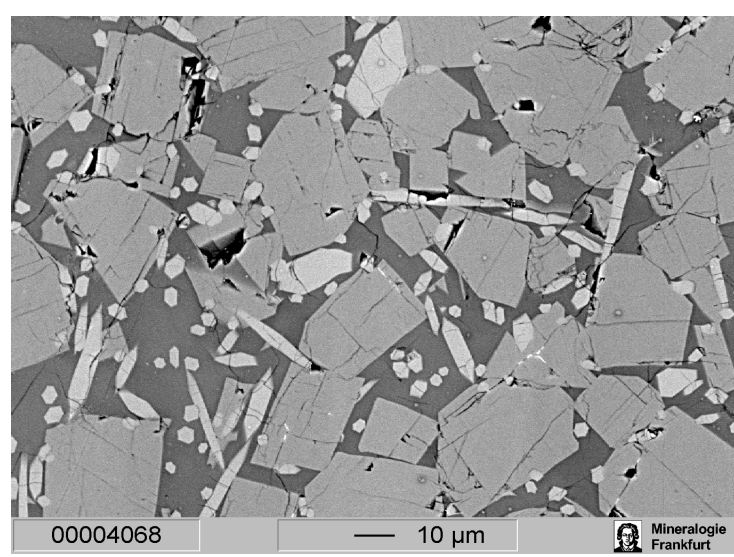

Figure 4: BSE image of run product \#1241 (5 GPa, $\left.1400^{\circ} \mathrm{C}\right)$ : $\mathrm{Ca}$-walstromite (isometric crystals) coexisting with an apatite phase (light prismatic crystals) within melt.

\section{REFERENCES}

Gasparik T., Wolf K., Smith C.M., 1994. Experimental determination of the phase relations in the $\mathrm{CaSiO}_{3}$ system from 8 to $15 \mathrm{GPa}$. Amer. Mineral. 79, 12191222.

Joswig, W., Stachel T., Harris J.W., Baur W.H., Brey G.P., 1999. New Ca-silicate inclusions in diamonds tracers form the lower mantle. Earh Planet Sci Lett $173,1-6$.

Stachel T., Harris J.W., Brey G.P., 2000. Kankan diamonds (Guinea) II: lower mantle inclusion parageneses. Contrib. Mineral. Petrol. 140, 16-27.

Walker D., Clark S.M., Jones R.L., Cranswick, 2000. Rapid methods for the calibration of solid-state detectors. J. Synchrotron Rad. 7, 18-21.

Contact: Stephan Buhre, Institut für Mineralogie, Universität Frankfurt am Main, 60054 Frankfurt, Germany, e-mail: buhre@em.uni-frankfurt.de 